\title{
Otelo, a tragédia da alteridade
}

\author{
Murilo Cavalcante Alves* \\ Universidade Federal de Alagoas \\ Maceió, Brasil \\ Recebido em: 23/04/2019 \\ Aceito em: 04/06/2019
}

\begin{abstract}
Ouvi as súplicas de Desdêmona, as suas palavras amorosas e puras, e a fúria do mouro, e a morte que este lhe deu entre aplausos frenéticos do público.
\end{abstract}

Machado de Assis. Dom Casmurro

Resumo: O artigo aborda a tragédia shakespeariana Otelo sob o ponto de vista da alteridade, e não do ciúme, como está sendo tradicionalmente analisada pela fortuna crítica do dramaturgo inglês. Nessa perspectiva, problematiza o papel relevante, mas usualmente ignorado, do epíteto "o mouro de Veneza", adicionado ao título da tragédia.

Palavras-chave: Alteridade. Otelo. Mouro. William Shakespeare.

Abstract: The paper deals with the Shakespearean tragedy Othello from the point of view of alterity, not jealousy, as has been traditionally analyzed by the critical fortune of the English playwright. In this perspective, it problematizes the relevant but usually ignored role of the epithet "the Moor of Venice", added to the title of the tragedy.

Keywords: Alterity. Othelo. Moor. William Shakespeare.

Résumé: L'article traite de la tragédie shakespearienne Othello du point de vue de l'altérité, et non de la jalousie, comme l'a traditionnellement analysé la fortune critique du dramaturge anglais. Dans cette perspective, il problématise le rôle pertinent mais généralement ignoré de l'épithète "le maure de Venise", ajoutée au titre de la tragédie.

Mot-clés: Altérité. Otelo. Maure. William Shakespeare. 


\section{Introdução}

As obras dramáticas de William Shakespeare se destacam não apenas por sua natureza literária, mas também pelas contribuições factuais-humanas, históricas, sociológicas e antropológicas, circunstâncias que ensejam no meio acadêmico uma recorrente necessidade de estudos destas obras. Obras primas como Hamlet, Macbeth, Romeu e Julieta, Rei Lear e Otelo, são responsáveis por uma fortuna crítica significativa dos críticos e estudiosos da literatura anglófona, sobretudo da tragédia Otelo, escrita em 1604.

Tradicionalmente, parte expressiva da fortuna crítica sobre esta última tragédia adota o pressuposto de que o tema da intriga é a inveja e o ciúme, ou então, que se trata de uma tragédia doméstica. Poucas são as análises críticas que adotam o ponto de vista da alteridade, isto é, de que o leitmotiv da tragédia se circunscreveria à construção preconceituosa do “Outro" - dentre estas, destacase pelo menos uma exceção, o estudo de Sirlei Santos Campos (2000), que adota a perspectiva de que a tragédia de Otelo é ser diferente num contexto totalmente hostil. Ou seja, o aspecto da alteridade, negligenciado pela maior parte dos analistas, só fica evidente quando se questiona o fato de que o Otelo da tragédia é um "mouro" (moor).

Determinar exatamente qual seria o significado atribuído ao termo "mouro" por Shakespeare, não é tarefa simples. Constatação a que se chega quando se efetua uma leitura minuciosa do texto dramático, e não se encontra explicitado em nenhuma parte, e de forma inequívoca, o significado do termo que, de pronto, lembra o contexto em que foi cunhado, isto é, o período de dominação islâmica da Península Ibérica, em que os mouros eram considerados invasores e, mais do que isso, "diferentes", no contexto da civilização ocidental cristã. Assim, diante dessa dificuldade, o presente artigo adota a estratégia de avaliar as conceptualizações do termo "mouro" (moor) e de como ele é retoricamente construído na tragédia, utilizando a perspectiva da crítica literária e cultural e do conceito de alteridade. Isso porque o termo em si insinua relações com outros termos congêneres, tais como "árabe", "negro”, “etíope”, “demônio” no contexto da obra analisada, fato que 
fica claramente delineado através da análise da fala dos personagens, quando estes se dirigem ou se referem a Otelo. A partir dessa perspectiva, chega-se à conclusão de que o termo "mouro" (moor), na tragédia Otelo, parece conceptualizar uma visão preconceituosa do "Outro", quer dizer, uma construção discriminatória efetivada através da retórica.

Inspirada em uma história de Hecatommithi, de Giovani Battista Giraldi, escrita em 1584, o Otelo de Shakespeare seguiu boa parte dos elementos originais, porém com algumas modificações. Segundo Pinho. et al (2006, p. 2), Shakespeare "[...] fez algumas modificações: atribuiu ao Mouro um caráter mais nobre e refinado e também uma função de destaque em Veneza; aumentou a importância de Emília na trama; acentuou a malignidade de Iago; criou novos personagens e eliminou outros.”

Um bom resumo da tragédia encontra-se delineado em Tamm (2006). Para esta análise, optou-se pela bela tradução de Onestaldo de Pennafort, publicada em 1968 pela editora Civilização Brasileira.

\section{Onestaldo de Pennafort: tradutor de Shakespeare}

Onestaldo de Pennafort Caldas (1902-1987), além de tradutor, foi também autor laureado. Seu primeiro livro de poesias, Escombros Floridos, foi publicado em 1921. Além de sua obra poética, dedicou-se à tradução, traduzindo diversas obras, entre elas Festas Galantes, de Paul Verlaine (1934), Romeu e Julieta (1940) e Otelo (1968), de William Shakespeare. Ao lado de sua produção poética, Pennafort desenvolveria também outra atividade profícua como tradutor de Apollinaire, Baudelaire, Cocteau, Goethe e Théophile Gautier para o nosso vernáculo. Durante a montagem de Otelo, em março de 1956, pela Companhia Tonia-Celi-Autran, Adolfo Celi (1968), diretor da peça, manifestou-se sobre a tradução de Pennafort, utilizada pelo grupo teatral, dizendo que:

[...] a tradução, conserva [...] rigor estético e fidelidade ao espírito do original, consegue ser simples, humana e, num termo teatral, 'corrida'. A diferenciação entre o estilo lírico-dramático de Otelo e Desdêmona, em 
contraposição com a linha cômico-satírica de Iago na primeira parte o sádico e intelectual gosto do mal no desenvolvimento da sua intriga; o convívio entre doçura e violência épica da peça, são indícios do alto grau artístico da tradução de Onestaldo de Pennafort e enriquece o repertório internacional em língua portuguesa. (Depoimento na contracapa do livro Otelo (1968), traduzido por Pennafort)

A tradução de Otelo também receberia referências elogiosas de Manuel Bandeira (1990, p. 675) - ele próprio tradutor de Hamlet; no livro Andorinha, Andorinha, ele diz: “Otelo, que está sendo levado no Dulcina, na magnífica tradução de Onestaldo de Pennafort e na interpretação magistral de Autran e Wagner e seus companheiros."

\section{Pennafort, crítico de Otelo}

Além de traduzir a obra, em um ensaio esclarecedor, intitulado Alguns aspectos de OTELO, que antecede sua tradução, Pennafort (1968, p. 17) pergunta:

Quem é Otelo? Uma simbolização do ciúme? Sobre ele o complexo de inferioridade, de cor? Qual o verdadeiro móvel da perversidade de Iago? Não será ele simplesmente a figuração do demônio, das forças do mal, como o gênio infernal da criação? E Desdêmona, será a representação, o símbolo, a imagem da fraqueza e da passividade femininas?

Tais questionamentos, de certo modo, antecipam algumas das visões sobre esta obra, abordadas por Harold Bloom (2001), e transcritas mais adiante neste artigo, os quais o próprio Pennafort não se exime de responder:

\footnotetext{
Responder de modo afirmativo a essas questões corresponderia praticamente a admitir o absurdo de que Shakespeare fosse capaz de escrever, no início do século XVI, um drama filosófico em que as personagens, em vez de concretas, fossem meros símbolos, meras abstrações figuradas. (PENNAFORT, 1968, p. 17-18)
}

Assim, a partir da leitura do ensaio do tradutor, depreende-se que o personagem Otelo não só não representa o Ciúme, como nem é mesmo uma natureza suspicaz e ciumenta, apesar de ter se deixado dominar pelo zelo amoroso e fique sob o império de paixão violenta durante boa parte do drama. Reforça tal 
ideia declinando a definição do próprio personagem sobre si mesmo como sendo a de alguém "que, sem saber amar, amou profundamente, e sem ser ciumento, compelido ao ciúme enlouqueceu" (PENNAFORT, 1968, p.18). Citando o personagem Ludovico, o crítico/tradutor lembra o alto conceito em que o Mouro era tido pelo senado, um “caráter privilegiado que nenhuma paixão pode abalar"; e o insuspeitíssimo Iago o pinta como homem sereno até no ardor das batalhas e a quem só um motivo muito sério poderia irritar - nem mesmo a morte do próprio irmão faz com que o Mouro perca a serenidade. Desdêmona confirmaria esse retrato do marido, quando diz: "O sol sob o qual nasceu (eufemismo que o designa negro) purgou o seu sangue de tais humores (o ciúme)." (PENNAFORT, 1968, p.1819). Quanto à tese de complexo de inferioridade, Pennafort diz que Otelo se antecipa na resposta: "Aqueles a quem devo a vida se assentavam em tronos reais (Etiópia) e quanto aos meus méritos, podem falar, e de cabeça erguida, para dizer que valho o orgulhoso troféu que conquistei” (PENNAFORT, 1968, p.19), isto é, Desdêmona, a filha veneziana do nobilíssimo Senador da República cognominado “O Magnífico”.

Do mesmo modo, Iago não é, para o crítico de Otelo, uma abstração. O motivo suficiente para suas ações é o fato de ter sido preterido na promoção a lugar-tenente de Otelo. Descarta, portanto, citando Coleridge (1772-1834), a rotulação do personagem "sob a fácil, cômoda e sumária classificação de símbolo demoníaco", pois "isso enfraqueceria a personagem dramática, tirando-lhe a sua humanidade" (PENNAFORT, 1968, p.19). Em síntese, para o tradutor e crítico de Shakespeare, a dimensão metafísica de Iago vale apenas indiretamente, como comparação, não como definição. E finalmente, a pergunta de Otelo a Desdêmona: “Vejamos, quem és tu?”, poderia assim ser respondida com suas próprias palavras em que exalta as qualidades da mulher, por isso que "não é ela uma mulher fraca e incolor." (PENNAFORT, 1968, p. 12) 


\section{A invenção humana de Otelo}

Outro crítico abalizado de Shakespeare, o norte-americano Harold Bloom (2001), considerado hoje um dos críticos mais instigantes de nossa época, autor, dentre outras obras agora clássicas, de A Angústia da Influência: uma Teoria da Poesia, e do citado O Cânone Ocidental: os Livros e a Escola do Tempo escreveu a biografia Shakespeare: a invenção do humano. Nesta obra, analisa uma a uma as criações literárias shakespearianas, decifrando a riqueza intemporal do gênio criativo do autor inglês. Para Bloom (2001), Shakespeare não apenas representou, mas efetivamente inventou o homem, daí o inusitado título de sua obra.

$\mathrm{Na}$ análise de Otelo, Bloom (2001) considera quase toda a fortuna crítica a respeito da obra, da qual se utiliza para fundamentar suas análises; ora elogiando a peça, ora criticando-a de forma vigorosa, mas sempre se utilizando de um estilo fluido e agradável.

A ideia central do capítulo sobre Otelo é a de sobremaneira resgatar a dignidade e a glória do Mouro, ou seja, repetindo os próprios termos do autor: “embora seja Iago o centro da peça [...], devemos resgatar a questão da dignidade e da glória de Otelo no início da trama”, pois uma nociva tradição da crítica moderna roubou o esplendor do herói, acentuando de tal modo a importância de Iago que ficam justificadas as palavras de Otelo: "Finda é a missão de Otelo." (BLOOM, 2001, p. 537).

Entretanto, surpreendentemente, para recuperar Otelo, Bloom diz ser necessário fixar o real papel e natureza de Iago: "Não chegaremos a uma avaliação justa de Otelo se subestimarmos Iago.” (BLOOM, 2001, p. 542). Para isso, começa seu estudo com uma epígrafe de William Hazlitt (1778-1830):

O personagem de Iago [é de uma] classe de indivíduos dotados de mescla de intensa atividade intelectual e total ausência de princípios morais, que ganham evidência às custas de terceiros, tentando confundir as fronteiras práticas entre o bem e o mal. (BLOOM, 2001, p. 536)

Desta citação parte então o argumento principal de Bloom (2001), que é o de humanizar Iago, afastando-o de toda abordagem de natureza metafísica, à qual 
vai se contrapor durante todo o resto de sua análise. Assim, para Bloom, "Iago é tão somente um exemplo extremo, isto é, de atividade intelectual doentia, de total indiferença ao bem e ao mal [...]" (BLOOM, 2001, p. 537). Mais ainda: "Não há parte do Inferno de Dante que Iago não pudesse habitar, de tão vasta a sua capacidade de perpetrar o mal." (BLOOM, 2001, p. 562). Apesar disso, “O “Alferes" é um filósofo." (BLOOM, 2001, p. 562).

Para o motivo do ódio de Iago, o autor do Cânone Ocidental afirma ser o mesmo de Satanás, do Paraíso Perdido, de Milton: "mérito não reconhecido." (BLOOM, 2001, p. 562). Descarta, assim, a justificativa apresentada por Iago de que tanto Otelo como Cássio teriam deitado com a mulher dele, Emília. Bloom (2001) justifica o comportamento de Otelo que, em sua opinião, não seria capaz de tal ato. Ademais, para Bloom, Iago "está sempre em guerra; é um piromaníaco moral, que ateia fogo à realidade" (BLOOM, 2001, p. 538). Afinal, "Iago é o maior estudo shakespeariano sobre ausência ontoteológica" (BLOOM, 2001, p. 539) e "ao guerrear contra Otelo, Iago luta contra a ontologia." (BLOOM, 2001, p. 539). Para Bloom, a guerra "é o meio mais puro de profetizar [...] A guerra é Deus", uma vez que se trata do jogo supremo: o conflito de vontades. E "Iago é o gênio do arbítrio que renasce a partir do desprezo que a guerra demonstra pela vontade." (BLOOM, 2001, p. 541-542).

Dessa forma, continua a ascensão de lago no panteão bloominiano, quando o crítico afirma: "Não devemos diminuir a genialidade de Iago; trata-se de um grande artista; [ele] brilha como teólogo niilista da morte de Deus; a característica mais singular de Iago, surpreendentemente, é a liberdade” (BLOOM, 2001, p. 540) Quer dizer, "entre todos os vilões da literatura, ele tem a honra nefasta de ocupar uma posição inatingível” (BLOOM, 2001, p. 543); melhor dizendo, na literatura moderna personagem algum supera Iago, "que continua a ser o demônio do Ocidente, um grande psicólogo, dramaturgo, crítico e teólogo da negatividade; como um joão-ninguém espiritual, Iago é universal, ou seja, pertence a muitos locais e a muitas épocas" (BLOOM, 2001, p. 543), pois “os seguidores de Iago estão em toda a parte" (BLOOM, 2001, p. 562). O crítico utiliza até elementos externos para justificar a grandeza do antagonista de Otelo: “A terrível grandeza de Iago é, 
também, o triunfo de Shakespeare com relação a Christopher Marlowe...” (BLOOM, 2001, p. 570). E, no seu exagero laudatório, Bloom chega mesmo a questionar: "Será que não apreciamos Iago, apesar da ambivalência de nossos sentimentos por ele?” (BLOOM, 2001, p. 570). E culmina, então, afirmando que “o único elemento sublime em Otelo é Iago.” (BLOOM, 2001, p. 547).

Reflita-se, então, sobre tais considerações do crítico: após tudo isso o que resta para Otelo, na tentativa de recuperação bloominiana? Pouco, muito pouco. Bloom começa reconhecendo ser difícil recuperar o esplendor de Otelo na peça, "uma vez que ele cai, tão prontamente, na conversa de Iago." (BLOOM, 2001, p. 538). Se é verdade que a motivação de Iago para seu ódio a Otelo teria sido sua troca por Cássio, Bloom não vê no texto nenhuma justificativa para que Otelo tenha feito tal opção. Simplesmente “Otelo enganou-se com Iago.”(BLOOM, 2001, p. 539). Ainda para o crítico americano, do ponto de vista dramático, a teatralidade de Iago é magistral, enquanto a de Otelo é problemática, brilhantemente problemática, pois “a tragédia de Otelo é, precisamente, o fato de Iago conhecê-lo melhor do que ele próprio se conhece.” (BLOOM, 2001, p. 551). E tece algumas asserções sobre o caráter nobre do Mouro, como: “Otelo tem plena consciência de que sua grandeza foi conquistada à custa de muito suor" (BLOOM, 2001, p. 551), porém “só é capaz de ver a si mesmo através de uma perspectiva grandiloquente. Apresenta-se como figura lendária, mítica, mais nobre do que qualquer romano da era clássica” (BLOOM, 2001, p. 551); mas a impressão que causa é, ao contrário, de que a personagem se torna muito pálida diante da figura grandiosa do seu adversário veneziano, até mesmo porque "Como podemos acreditar no heroísmo, na grandeza e na natureza benévola de um protagonista tão catastrófico?" (BLOOM, 2001, p. 551). E, apesar de ser "um indivíduo admirável, um grande homem que, em pouco tempo, é destruído" por ser "genuinamente homérico", sua “simplicidade heroica é, também, uma cegueira heroica." (BLOOM, 2001, p. 551).

Para Harold Bloom (2001), a catástrofe primeira da peça seria "a queda de Iago”, que estabelece um paradigma para a queda de Satanás, em Milton (Paraíso Perdido). Isto significa dizer que: 
o Deus de Milton, assim como Otelo, rebaixa o mais devotado dos seus servidores, e o magoado Satanás rebela-se. Incapaz de derrubar o ser Supremo, Satanás derrota Adão e Eva; mas o sutil Iago vai mais longe, pois seu único deus é o próprio Otelo, cuja queda se torna a vingança maior de Iago. (BLOOM, 2001, p. 539)

Apesar disso, não se enganem, pois para Bloom (2001) a tragédia Otelo não é de natureza metafísica, apesar de Iago, que afirma ser tão somente crítico, é, também, tão somente metafísico! Lança, então, um questionamento determinante sobre o personagem: "Quem, antes de Iago, na literatura ou na vida, dominou com tanta maestria as artes da desinformação, desorientação e desordem?” (BLOOM, 2001, p. 540) E, para evitar a única resposta natural, que seria de dimensão metafísica, contra-argumenta:

O débito que o Satanás criado por Milton tem com Iago é tamanho que somos tentados a interpretar a catástrofe de Otelo em termos da Queda de Adão, e a ver no declínio de Lúcifer indícios da concepção de Iago. Porém, ainda que o Mouro de Shakespeare seja batizado, Otelo não é peça cristã [...] Iago, jocosamente, invoca uma 'entidade do inferno', mas ele não é apenas um ser diabólico. Iago é [apenas] a Eterna Guerra. (BLOOM, 2001, p. 541).

E aqui é bastante reveladora a forma como Bloom (2001) define a "religião" de Iago: "a religião de Iago é a guerra, em todas as frentes - nas ruas, nos campos de batalha, no abismo que é o seu próprio interior. Guerra em todas as frentes é uma religião." (BLOOM, 2001, p. 541).

Por isso que o autor da Invenção do Humano expressa seu mais vivo desagrado - ele na verdade chama de perplexidade - diante do debate crítico em torno da questão de Shakespeare ter sido protestante ou católico, pois para ele as tragédias shakespearianas não são nem uma coisa nem outra. $\mathrm{Na}$ verdade, para o crítico, Iago apresenta elementos gnósticos heréticos, mas Shakespeare não era gnóstico, nem hermeticista, nem ocultista. Ou seja, “[...] comparado a Iago, Satanás fica em desvantagem, por ter de atuar em uma escala demasiadamente cósmica: a natureza inteira cai com Adão e Eva.” (BLOOM, 2001, p. 570). Para Bloom (2001), Iago manipula Otelo, explorando o que o Mouro tem em comum com o Deus ciumento dos judeus, cristãos e muçulmanos: a vulnerabilidade à traição. E aqui 
amplifica o motivo de Iago para perder Otelo: "Sentir-se traído por um deus, Marte ou Javé, e buscar a reparação do amor-próprio ferido, a meu ver, constituem os motivos mais justificáveis para qualquer vilão; daí o desígnio de fazer o deus retornar ao abrigo no qual o vilão se encontra.” (BLOOM, 2001, p. 575). Quer dizer, “Caim, rejeitado por Javé em favor de Abel, é pai de Iago, assim como Iago é o precursor do Satanás de Milton.” (BLOOM, 2001, p. 584). Enfim, Bloom conclui que “Otelo, assim como Rei Lear e Macbeth, é uma radical visão do mal” (BLOOM, 2001, p. 583) e "não tem uma dimensão transcendental, talvez, porque a religião da guerra não o permita." (BLOOM, 2001, p. 583).

$\mathrm{Na}$ verdade, o eminente crítico, na medida em que tenta dessacralizar e desontologizar a tragédia Otelo, só consegue transformá-la mais ainda em tragédia metafísica. A tentativa frustrada de humanizar Iago só demonstra que este, por ser uma construção da linguagem, por conseguinte fictício, é irreal, porquanto ignoram-se suas origens; e, também, uma vez que se torna uma construção de si mesmo, pode assim assumir a forma genérica e grandiosa de um verdadeiro demônio. E a maneira como Bloom o desconstrói, projeta-lhe uma malignidade tão diabólica e metafísica, que só lembra mesmo o Satanás bíblico. Não é Iago mesmo quem diz tal qual o Lúcifer cristão: "Nunca mostro o que sou.”? Por isso que o caráter antinatural de Iago como personagem é metafísico, quer dizer, seu fascínio natural pelo mal tem gênese bíblica. Por ser uma construção da linguagem, Iago é principalmente uma grande metáfora do maligno, do adversário do homem tão bem delineado pela tradição islâmica como Shaitan ou Iblis, cognominado de Lúcifer pela tradição cristã. Este, como o Iago da tragédia, é o insinuador, o tentador, aquele que desvia, que se contrapõe, que põe em movimento as molas das paixões que conduzem os humanos ao desvio. Pois não é Iago quem diz: "Quando os demônios querem induzir-nos aos mais negros pecados, principiam por suscitá-los sob as aparências mais angelicais, como ora faço”? (Ato II, Cena III).

Quando Iago se contrapõe à afirmativa de São Paulo e nunca mostra o que realmente é, denota exatamente a natureza enganadora do adversário do homem, tão bem delineada pela tradição islâmica: "Disse: Juro que, por me teres extraviado, desviá-los-ei da Tua senda reta. E, então, atacá-los-ei pela frente e por trás, pela 
direita e pela esquerda e não acharás, entre eles, muitos agradecidos.” (ALCORÃO, 2004, Surata 7, 16-17; p. 176). Isto lembra, inclusive, a noção bloominiana da religião de Iago: "Guerra em todas as frentes é uma religião." (BLOOM, 2001, p. 541). O motivo de Iago? Pode ser nenhum, ou qualquer um! Como demônio da maldade não precisa se justificar, sua própria natureza o justifica. A liberdade, ou seja, o livre arbítrio de Iago para atuar livremente é bíblico, portanto, da mesma natureza genésica da liberação luciferiana. Aliás, é injustificável o porquê da surpresa de Bloom (2001) com o comportamento da personagem Emília, ao surpreender Iago, uma vez que, biblicamente, é a figura da mulher que torna possível tal desmascaramento. Por outro lado, sua leitura do Deus judaico-cristão-islâmico é pueril, é tão somente um construto antropomórfico segundo imagem e limitações humanas. Quando afirma que Iago é incapaz de ferir Otelo fisicamente, porque a um deus só se atinge espiritual ou metafisicamente, Bloom (2001) só faz reforçar a natureza satânica de Iago que, a exemplo de Lúcifer, desobedece ao Criador e só consegue atingi-lo através da Sua criação humana. E para Otelo, é certamente Desdêmona (a desditosa) quem será atingida.

Inegavelmente, o Otelo de Harold Bloom (2001) é de uma densidade crítica portentosa. Sem esquecer o fato de que é permeado de farta intertextualidade bíblica e filosófica. A obra desse erudito estudioso do cânone shakespeariano já é considerada como uma das contribuições mais vigorosas, e polêmicas, ao estudo dos enigmas que os textos suscitam, e o capítulo sobre Otelo é um ilustrativo exemplo disso. A ilustração mais contundente da controvertida abordagem do crítico é dada por ele mesmo, quando desabafa numa entrevista:

Há pouco recebi um livro com 18 ensaios escritos por pessoas que nem conheço, chamado O Shakespeare de Harold Bloom. [...] São de arrepiar. São todos peças de abuso e vituperação escritas por feministas, marxistas, neo-historicistas, seguidores de várias epidemias francesas, como eu as denomino. Uma senhora indiana muito raivosa, que não conheço, me acusa de ser um 'patriago neurocêntrico'. Outra, porque eu não acho que a negritude de Otelo seja crucial para a composição deste personagem, e porque eu não concordo que Caliban seja um negro de modo algum, acusa-me de racismo, de ser contra os negros. [...] Para elas tudo se resume a política. E nem sequer é política, o que chamam de política. É política acadêmica. (CAVENDISH, 2002, p. 82) 
É verdade que o ensaio de Harold Bloom (2001) é uma verdadeira dissecação dos personagens e de suas motivações. Contudo, se tenta recuperar a figura de Otelo, nada mais faz do que ressaltar a personalidade grandiosa de Iago. Tal qual o tradutor brasileiro de Otelo, Bloom afirma que a motivação para o ódio de Iago a Otelo é "o mérito não reconhecido". Entretanto, se tenta descaracterizar a peça como de fundamentação metafísica, seu próprio texto o desmente, porque a maior parte da sua argumentação remete-nos o tempo todo para tais características. Suas próprias palavras contradizem-no: "A tragédia, como gênero dramático, não é, necessariamente, metafísica, mas Iago, que afirma ser tão somente crítico, é, também, tão somente metafísico" (BLOOM, 2001, p. 539).

Por outro lado, o crítico afirma que Otelo tem plena consciência de sua grandeza, conquistada à custa de muito suor. Para ele, Otelo é um mercenário, um soldado negro a serviço do Estado veneziano. Sua falha - "hamartia", se fosse possível aplicar este conceito da tragédia grega - é que só consegue ver-se através de uma perspectiva grandiloquente, pois se apresenta como figura lendária, mítica, mais nobre do que qualquer romano da era clássica ("Otelo, conforme César, costuma referir-se a si mesmo na terceira pessoa") (BLOOM, 2001, p. 551). Sua tragédia é precisamente o fato de Iago conhecê-lo melhor do que ele próprio se conhece. É apenas um grande comandante, conhecedor da guerra e seus limites, mas conhece pouco mais do que isso, e que não pode saber que pouco sabe. Continua Bloom (2001): possui um ego grandioso, em termos de magnitude, mas vê a si mesmo de longe, por assim dizer; de perto, é incapaz de confrontar o vazio que existe no centro do seu ser. Dessa maneira, em qualquer hipótese, Otelo é impotente diante de Iago, ou seja, é sempre a antítese deste. Já Desdêmona é um milagre de sinceridade, porém tem uma dupla fragilidade: com relação ao marido e a Iago. E pior: escolheu mal seu marido. Ainda para Bloom: "Se, no início, ou no final da peça, Otelo é tão somente a soma total das descrições que faz de si próprio, então, pode ser considerado um verdadeiro festival de personalidades." (BLOOM, 2001, p. 553). E indaga: "Como podemos acreditar no heroísmo, na grandeza e na natureza benévola de um protagonista tão catastrófico?” (BLOOM, 2001, p. 553). 
Para o autor de Shakespeare: a invenção do humano, Otelo parece deslocado, este é o dilema sociopolítico do personagem, um mouro heroico no comando das forças armadas de Veneza, sofisticada em sua decadência - ontem e hoje. E Shakespeare teria combinado mercenarismo e romance em seu retrato de Otelo, e a mistura para ele, Bloom (2001), é inconsistente. Citando Reuben Bower (1935), diz, ao se referir a Otelo: "Sua simplicidade heroica é também, uma cegueira heroica. Tal característica faz parte do herói 'ideal' da metáfora shakespeariana.” (BLOOM, 2001, p. 554). Então, a referida metáfora, agora não mais homérica, estender-se-ia ao profissionalismo de um grande soldado mercenário, um negro heroico a serviço de uma sociedade branca altamente decadente. Otelo não faria o tipo doméstico, porquanto a carreira militar o realiza plenamente. Se Desdêmona se apaixona pelo guerreiro em Otelo, e este pelo sentimento que ela alimenta por ele, o casamento não altera a natureza de Otelo, embora altere seu relacionamento com Veneza, tornando-o, mais do que nunca, um intruso. Em tese, são esses os principais argumentos utilizados por Harold Bloom (2001).

\section{Das etimologias em Otelo}

Como se disse antes, na leitura do título do drama está embutida uma dúvida pouco explorada pelos críticos e que se relaciona ao aposto colado ao nome Otelo: “o Mouro de Veneza”, associado por muitos tradutores da obra. Bloom (2001), no seu ensaio, evita tocar na questão e chega mesmo a dizer que ela não é relevante no entendimento da tragédia. Ora, sabe-se que o aposto é um elemento relevante na individuação de um substantivo, explicando-o, amplificando-o ou elucidando-o através de detalhes, que o nome por si só não conseguiria fazer. Assim, no presente caso, a questão é saber exatamente o que o termo "Mouro" significa para Shakespeare e todos os outros personagens da tragédia. Inclusive, por que se é levado a associá-lo, de imediato, a árabe, ou a muçulmano. Eis o que diz, por exemplo, sobre esse termo, The American Heritage Dictionary of the English Language (1975): 


\section{BLACKAMOOR}

NOUN: Offensive. A dark-skinned person, especially a person from northern Africa.

ETYMOLOGY: black + -a-, of unknown origin + Moor.

MOOR

NOUN: 1. A member of a Muslim people of mixed Berber and Arab descent, now living in northwest Africa. 2. One of the Muslims who invaded Spain in the $8^{\text {th }}$ century and established a civilization in Andalusia that lasted until the late $15^{\text {th }}$ century.

ETYMOLOGY: Middle English More, from Old French, from Medieval Latin Mörus, from Latin Maurus, Mauritanian, from Greek Mauros.

$M O R O$

NOUN: Inflected form: pl. Moro or Mo:ros

1. A member of any of the predominantly Muslim Malay tribes of the southern Philippines.

2. Any of the Austronesian languages of the Moro.

ETYMOLOGY: Spanish, Moor, Muslim, Moro, from Latin Maurus, Moro. (p. 137)

Enquanto o Dicionário de Nomes, Termos e Conceitos Históricos, de Azevedo (1990, p. 275), amplia as informações a respeito do vocábulo:

MOUROS. Nome pelo qual, de maneira geral, eram designados, na Península Ibérica, durante a Idade Média, os muçulmanos ali instalados: árabes, berberes e outros. O termo foi especialmente empregado com relação aos que viviam em território cristão por força da capitulação de cidades ou do cativeiro de guerra. (AZEVEDO, 1990, p. 275)

Esta última definição se torna extremamente útil porque remete para o corpo da tragédia em que se percebe como Otelo, ao falar sobre suas origens, revela um detalhe importante a este respeito: "Contava-lhe de como, de uma feita, escapara por um triz de achar a morte certa numa brecha, e de outra em que, caindo prisioneiro de insolente inimigo, fui vendido como escravo e em seguida resgatado." (SHAKESPEARE,1969, Ato I, Cena III; grifo nosso).

O termo, porém, pode assumir outras acepções, como “1. Entre os romanos, denominação dada aos berberes independentes. 4. Da antiga Mauritânia; do Maghreb. 5. Moreno, trigueiro. 6. Fig. Não batizado.” (A GRANDE ENCICLOPÉDIA LAROUSSE CULTURAL, 1998, p. 4108, grifo nosso). Acrescenta então duas outras informações importantes, que encontram apoio no texto shakespeariano: Otelo era negro, porém batizado. De forma diversa, Pennafort, no seu ensaio, insere uma informação após uma fala de Otelo (SHAKESPEARE, 1969, Ato I, Cena II), que, 
entretanto, não cita no corpo da peça: "Aqueles a quem devo a vida se assentavam em tronos reais (Etiópia)...” E ser etíope significa “2. P. ext. Homem de raça negra; africano." (GRANDE ENCICLOPÉDIA LAROUSSE CULTURAL, 1998, p. 2286). De outro modo, Iago chama Otelo de "cavalo da Berberia", atribuindo-lhe assim uma origem berbere. ${ }^{1}$ Enfim, F. C. de Almeida Medeiros (1969, p. 785) diz que "para Shakespeare, moor era sinônimo de negro", ou ainda: "O diabo, [...], é o próprio Otelo, pois, para Shakespeare, mouro, negro e diabo significavam a mesma coisa." (MEDEIROS, 1969, p. 785). Assim, diante de tais informações, a que conclusão deve-se chegar a respeito do termo "mouro"? E mais importante: o que significava exatamente ser "mouro" na época de Shakespeare?

Uma referência importante na determinação dessa resposta é o estudo Othello's Predecessors: Moors in Renaissance Popular Literature (2006), que traz um pouco da visão renascentista sobre os moors, encontrados em dramas contemporâneos de Shakespeare, de autores como George Peele (The Battle of Alcazar,[1594?]) e Thomas Dekker (Lust's Dominion, or the Lascivious Queen,[160o?]). E, dentre estes, um texto que oferece uma visão histórica dos mouros segundo Leo Africanus, que escreveu The History and Description of Africa (1600).

Nestes textos, todos os personagens que falam são mouros. No texto de Peele (1589), por exemplo, o mouro é alcunhado de “barbarous Moore”. Por outro lado, há que se considerar que em Titus Andronicus (SHAKESPEARE, 1969) várias passagens da peça associam mouro a negro: "Aarão terá a alma tão negra quanto a face” (Ato III, Cena I); “o mouro negro como carvão” (SHAKESPEARE, 1969, Ato III, Cena II); "Infeliz, horrível, negra e sinistra linhagem!" (SHAKESPEARE, 1969, Ato IV, Cena II); enfim, também no Mercador de Veneza, as associações da cor negra ao mouro também se evidenciam. Porém, é no texto de Leo Africanus (160o) que fica mais evidente os estereótipos a respeito dos africanos e mouros na época shakespeariana. Inclusive se especula que por esse texto ser bastante divulgado na Inglaterra elisabetana, talvez o próprio Shakespeare o conhecesse. O texto de

${ }_{1}^{1}$ Berbere, s.m. (ár. berber) S. 2 gén. Habitante da Berberia, na África do Norte. (Dicionário Prático llustrado "Lello", p. 159) 
Africanus, sobretudo a parte final, revela um pouco dessa visão eurocêntrica/etnocêntrica preconceituosa sobre o horizonte africano e seus habitantes:

Os negros igualmente levam uma espécie de vida bestial, sendo totalmente destituídos do uso da razão, da destreza do bom senso e de todas as habilidades. Sim, eles também se comportam como se tivessem continuamente vivido em uma floresta entre os animais selvagens. (AFRICANUS, 16oo, não paginado) (Tradução nossa). ${ }^{2}$

\section{Otelo personae Otelo}

Outra discussão inevitável se relaciona à visão do personagem Otelo sobre si mesmo, uma vez que, como se verá mais adiante, o general chega a incorporar a construção retórica que Iago faz sobre ele em sua identidade de mouro. E isto conduz à pergunta: afinal, quem é Otelo para o próprio Otelo?

Logo no início da peça o próprio Mouro se vê como um aventureiro cujos limites à sua vida errante foram dados por Desdêmona: "se não fosse por este amor que a Desdêmona consagro, jamais poria freios e fronteiras à minha vida aventurosa e errante." (Ato I, Cena I). Contudo, ele se tem na conta de pessoa de caráter: "Meu caráter, a minha posição e a pureza da minha consciência, hão de justificar-me." (Ato I, Cena II). Acha-se rude no falar e inábil no versar a linguagem da paz, porque é, sobretudo, um soldado, um guerreiro, afeito às provações mais duras: "E deste vasto mundo bem pouco ou nada sei dizer, senão das suas sedições, feitos de guerra e de armas.” (Ato III, Cena I). Afirma, no entanto, estar a salvo dos “apetites da paixão" que acalmam "o fogo dos sentidos", pois "tais ardores já se apagaram com a mocidade." (Ato III, Cena I). Sua confiança, assim, baseia-se nos preceitos oriundos dos ensinamentos militares, por isso confia piamente em Iago, um personagem que, no entanto, é em todos os sentidos enganoso ("Este homem na verdade é muito escrupuloso e tem experiência e acuidade bastante para ir ao fundo das ações humanas"; “deixarei meu alferes; é pessoa de toda a confiança”, diz

2 "The Negroes likewise leade a beastly kinde of life, being vtterly destitute of the vse of reason, of dexteritie of wit, and of all artes. Yea they so behaue themselues, as if they had continually liued in a forrest among wilde beasts." (AFRICANUS, 1600) 
isso ao confiar a própria esposa ao seu maior inimigo). Avalia mal sua relação com os outros ("eu sou benquisto aqui", ao se referir à cidade e a seus habitantes). Em um determinado momento se sente inferior, e aqui assoma o drama do próprio personagem com a cor da sua pele: "Talvez por eu ser negro e não ter o falar adocicado e as maneiras suaves dos galantes da corte...” (Ato III, Cena III). E lamenta a diferença de idade com relação à esposa: "Ou quem sabe porque já vou descendo o vale inclinado dos anos...” (Ato III, Cena III). Enfim, julga-se principalmente honrado: "Pois em tudo o que fiz, não me moveu o ódio e sim a honra" (Ato V, Cena II).

Quer dizer, a impressão que causa é a de ser um personagem grandioso, mais afeito às tarefas militares do que à vida prática, daí sua pouca habilidade em discernir as mínimas coisas do cotidiano. Por outro lado, sente-se também inferior, já que a circunstância de ser negro de algum modo o afeta sensivelmente. Otelo não se percebe como um estrangeiro em uma terra estranha, sujeito a uma vulnerabilidade incomum por ser mouro, isto é, “o outro”, “o diferente”; rodeado por italianos e cipriotas, sua aparente aceitação social se dá apenas porque tem um papel a cumprir naquela sociedade que recusa os "diferentes". Enfim, a tragicidade de sua condição se dá por não conseguir discernir sua real identidade num contexto aparentemente benéfico, mas que, no entanto, lhe é o tempo todo hostil. Daí ser facilmente manipulado pelo seu subordinado Iago, portador de uma retórica poderosíssima.

\section{Os personagens olham para Otelo}

E para os demais personagens, quem é Otelo? De início, quando se começa a ler o drama, pouco se revela da opinião destes sobre o protagonista. Apenas Iago, desde o começo, começa a destilar suas invectivas sobre o personagem principal da peça. Para Iago, Otelo se constitui num ser compósito de boas e más qualidades, porém fica difícil determinar quando o Alferes está sendo sincero, por conta de seu caráter demoníaco como antagonista do Mouro. Ele diz: "Embora odiando o Mouro, reconheço que, além de nobre, é fiel e carinhoso, devendo ser um ótimo 
marido." (Ato II, Cena 1). Chega a insinuar a inferioridade do Mouro, quando questiona se ele teria prazer. Em seguida, compara-o a "um velho carneiro negro" e ao próprio diabo, quer dizer a um cavalo, um “cavalo da Berberia”, que produziria toda uma geração de corcéis e ginetes. Em outro momento, diz que "esses mouros são volúveis por natureza”, gostam de dinheiro, e faz uma comparação entre ele, o "barbaresco nômade”, e a "veneziana arquiladina” (Desdêmona). Porém, sabe que, "por natureza, o Mouro é confiante [...] Julga honestos os homens que o parecem [...] [quer dizer, avalia mal as pessoas]. Deixar-se-á conduzir pelo focinho, docilissimamente, como um asno" (Ato I, Cena III). Questiona, enfim, o porquê da escolha de Desdêmona: "E que prazer podem [os olhos] encontrar na contemplação desse bruxo [Otelo]?”, pois “a fascinação da beleza, a conformidade das idades, do gosto, sedução de maneiras, - [de] tudo isso o Mouro é desprovido” (Ato II, Cena I).

De forma semelhante, Brabâncio, pai de Desdêmona, ao saber que sua filha havia sido raptada (falsamente) por Otelo, deixa aflorar a real visão que ele tem do Mouro (Otelo, ingenuamente, achava que o pai de sua amada o apreciava): “[...] abandonar o lar paterno e se entregar aos braços ferrugentos de um ser tal como tu, feito para inspirar terror e não prazer!" (Ato I, Cena III). Ademais, acusa o general de "corrutor dos nossos bons costumes e praticante de artes proibidas" (Ato I, Cena III). Destaca, inclusive, as diferenças sociais entre os dois amantes: "Com tal feitio, educação, idade, pudor, estirpe - que mais diga, enfim - deixar-se apaixonar por alguém que, antes disso, ela não fitaria sem horror!" (Ato I, Cena III).

Quanto a Rodrigo, destaca a negritude e condição "bárbara” de Otelo: "Que sorte a dele, então, se com aquela beiçola, consegue abocanhá-la!”, ou então: “estrangeiro nômade, sem eira nem beira” (quer dizer: sem pátria e sem lar) (Ato I, Cena I). Os senhores de Veneza, aparentemente, têm-no em alta conta, apesar do preconceito de raça, como revela uma frase do Doge a seu respeito: "Se o emblema da virtude é a alvura, eu asseguro, Senhor, que o vosso genro [Otelo] é mais branco que escuro." (Ato I, Cena III). Finalmente, Desdêmona diz: "No espírito de Otelo é que vi seu semblante. E ao seu valor e gloriosos feitos consagrei a minha alma e o meu destino." (Ato I, Cena 3). "E se meu nobre Mouro não fosse 
limpo de pensamento e isento de ciumeiras tolas” (Ato III, Cena IV). Pergunta Emília: "Ele não é ciumento?” Responde Desdêmona: “Quem? Ele? Creio que o sol, sob o qual nasceu, purgou o seu sangue de tais humores." (Ato III, Cena IV). Mesmo assim, Emília não se convence, e no final trágico, lamentando a escolha da amiga, diz: "ela enjeitou tantos partidos bons e deixou pai, família, amigos, pátria, tudo" (Ato IV, Cena II). E diz para Otelo: "Ela era um anjo tão certo como sois um diabo negro!" (Ato V, Cena II, grifo nosso). Mas surge uma dúvida sobre o que Cássio quer dizer, quando afirma: "Há almas que devem ser salvas e almas que não devem ser salvas." (Ato II, Cena III). E, logo em seguida, conclui: "Quanto a mim — sem ofensa ao General, nem a pessoa alguma de qualidade, - espero ser salvo.” (Ato II, Cena III); seria pelo fato de Otelo ser cristão convertido? Enfim, ouçam Ludovico: "Então é este aquele nobre Mouro cujo valor altíssimo o Senado sempre, com voz unânime proclama? Este o caráter privilegiado que nenhuma paixão pode abalar? A sólida virtude invulnerável aos tiros da desgraça e aos dardos da fortuna?" (Ato IV, Cena I), Iago responde: "Ele é como é. Mas eu é que não posso dizer-vos como deveria ser. E se não é como devia, então prouvesse aos Céus que o fosse.” ( Ato IV, Cena I).

\section{Iago: a construção retórica da alteridade}

Sirlei Santos Campos (2000) critica A. C. Bradley (1851-1935) que, ao analisar os personagens de Otelo, desconsidera a relevância da circunstância deste ser mouro, alegando que não se deve historicizar Shakespeare. Para a autora, a tragédia Otelo parece perder muito de sua significação "se a personagem trágica Otelo não for analisada levando-se em conta sua cor e raça, uma vez que Shakespeare aproveitou o mito do outro para criar seu herói trágico para uma plateia (inglesa) que não tinha quase contato e conhecimento a respeito dos mouros." (CAMPOS, 200o, p. 2).

Campos (200o) destaca ainda que ser mouro, no século XVII, era "sinônimo de inferioridade, representava um potencial para transgressões, para impurezas relacionadas principalmente à sexualidade. Aos mouros era atribuída a cor negra, 
o que na época simbolizava o mal.” (2000, p. 2). Resta, então, saber como esta imagem é processada no corpo da própria peça, uma vez que Shakespeare, através de Iago, executa todo um processo retórico de construção da alteridade.

De certo modo, pode-se dizer, citando ainda Campos (2000), que Iago traça o destino de Otelo, ou melhor, do outro. Quase tudo que Otelo é compelido a fazer ele o realiza devido à poderosa retórica daquele que era seu subordinado, Iago. Em outros termos, a relação entre os dois personagens se dá através de uma espécie de jogo de palavras. O poder de Iago consiste no domínio da chamada ars rethorica, quer dizer, em estratégias de linguagem como meio de persuasão que, inevitavelmente, conduzem Otelo à perdição. Iago consegue fazer despertar em Otelo os sentimentos mais primitivos, aqueles que reforçariam seus instintos e justificariam sua condição de bárbaro. Ou seja, Iago faz com que o mouro veja a si mesmo como diferente, pois ele, Iago, detém o poder de embriagar: "Otelo parece embriagado pela linguagem de seu subalterno" e, esta "assimilação da linguagem de Iago culmina com o transe que levará Otelo a matar sua própria esposa.” (CAMPOS, 200o, p. 5). O discurso do Alferes está totalmente construído sob o viés da diferença, isto é, a tragédia Otelo se dá entre mundos distintos que se confrontam. Nesse sentido, a oposição Iago versus Otelo é uma oposição retórica, de domínios distintos da palavra, principal meio de persuasão. A mesma autora, agora citando Bakhtin, afirma que "a palavra é o local onde ocorrem os conflitos dos valores sociais contraditórios, além de acompanhar toda criação ideológica.” (BAKHTIN apud CAMPOS, 200o, p. 6).

A questão, então, se resume nisto: como os solilóquios de Iago revelam suas intenções e seu caráter (ethos)? Mais ainda, como ele consegue motivar Otelo a perpetrar o ato, este sim bárbaro, de assassinar Desdêmona? Bill Long (2006) comenta que se o discurso em Otelo é usado para criar ou veicular a ideia de beleza, nobreza ou bondade, para Iago, ao contrário, o discurso é tão somente um instrumento para manipular o mundo em seu próprio benefício. É através dos solilóquios que Shakespeare revela o ethos das suas personagens principais. Os solilóquios de Iago revelam seus motivos, seu modus operandi e suas intenções. Vejam, por exemplo, como ilustração, esta cena em que Iago se auto-revela: "Nem 
todos os patrões do mundo devem ser bem servidos. Sirvo a mim próprio apenas, quando o sirvo. [...] Nunca mostro quem sou! (Ato I, Cena I); [...] De nós mesmos depende sermos deste ou daquele feitio. O nosso corpo é uma horta de que o nosso arbítrio é o hortelão.” (Ato I, Cena III)

Interessante é que, no decorrer da tragédia, Iago é tido como honesto pelo próprio Otelo, que não consegue ver por baixo das aparências a real natureza de seu subordinado: "Se vos apraz, deixarei meu alferes; é pessoa de toda confiança. [...] Honesto Iago, confio-te Desdêmona...” (Ato I, Cena III). Observa ainda Long (2006) que é a simplicidade de seu discurso e a clareza de significado do ponto de vista gramatical que sustenta a reputação honesta de Iago. Ou seja, aplicado a Iago, a palavra "honest" implica naquilo que hoje denominamos de "com os pés no chão": uma pessoa "honesta" é alguém que não pretende viver através de princípios, mas sim aquela que diz as coisas abertamente e de forma franca. Em síntese, o termo sugeriria, em Shakespeare, transparência ou ausência de sutileza.

Reboul (1998) observa que, para os antigos, os gêneros oratórios eram três: o judiciário, o deliberativo e o epidíctico. Isto porque, segundo Aristóteles (Apud REBOUL, 1998, p. 45), existiriam três espécies de plateia e é a necessidade de adaptar-se a estas que confere traços distintos a cada gênero: de acordo com as pessoas a quem nos dirigimos, nem sempre falaremos do mesmo modo. Sendo assim, o discurso judiciário ou forense tem como auditório o tribunal; o deliberativo, o Senado e, o epidíctico, espectadores diversos, ou seja, todos os que assistem a discursos panegíricos, orações fúnebres e outras. (REBOUL, 1998, p. 4445). No entanto, os atos dos três discursos não são os mesmos. Se o judiciário acusa (acusação) ou defende (defesa), o deliberativo aconselha ou desaconselha em todas as questões que se relacionam com a cidade, como paz ou guerra, defesa, impostos, orçamento, importações, legislação, etc., enquanto o epidíctico censura e, muitas vezes, louva ora um homem ou uma categoria de homens, ora uma cidade, ora seres lendários. Por sua vez, os valores que servem de normas a esses discursos não são os mesmos. O judiciário diz respeito ao justo e ao injusto, enquanto o deliberativo diz respeito ao útil e ao nocivo. Quanto ao epidíctico, "os valores que o inspiram são o nobre e o vil (kalon, aiskhron).” (REBOUL, 1998, p. 44-45). 
No discurso de Iago identifica-se a natureza epidíctica de sua retórica: os valores inspirados por esta são os mais vis. Manipula habilidosamente as técnicas retóricas para enganar e convencer. Ele é um verdadeiro manipulador da psique humana. Seus solilóquios e diálogos revelam que é um artífice da linguagem conotativa e metafórica, dono de uma imaginação inflamatória que utiliza apelos emocionais, silêncios estratégicos, hesitações de caráter dúbio, perguntas capciosas, repetições significativas e, insinuações maldosas. Só isso explica a maneira como consegue enganar a todos: convence Otelo de que Cássio é um bêbedo, um soldado desleal, ou que Desdêmona é uma esperta prostituta. Ou provoca no próprio Otelo a dúvida com relação à sua própria identidade de mouro, que afinal o próprio Otelo chega a recusar, ao se pretender europeu. Enfim, a retórica do oponente de Otelo apela ora para a razão (logos), ora para a emoção (pathos), ou ainda, para o caráter (ethos) do seu oponente, manipulando de maneira efetiva todos os recursos da retórica para construir a alteridade daquele que pretende, e consegue, finalmente, aniquilar.

\section{To be or not to be moor}

Campos (2000, p. 6) continua a dizer, agora se detendo sobre o trágico em Otelo, que a tragicidade se dá através da força de um poder de assimilação cultural que na peça é metaforicamente representado por lago - este faz com que "o mouro veja a si mesmo como diferente". Ou seja, "recusando-se a aceitar o que vê, ele [o mouro] reforça a construção europeia a seu respeito." (CAMPOS, 200o, p. 6)

A construção retórica de Shakespeare/Iago se dá desde o início ao chamar a atenção de todos para o contraste físico do personagem e, através da imaginação, insinuar em suas ações que ele é capaz de perpetrar atos pecaminosos ou que contrariam o contexto europeu. Não é sem razão que Iago, logo no começo da tragédia, compara Otelo a animais. Vejam, por exemplo, o momento em que começa a pôr seu plano maléfico em ação, incitando o pai de Desdêmona, Brabâncio, contra Otelo: 
Por Deus, senhor! Fostes roubado! [...] Agora, neste instante, agora mesmo, um velho carneiro negro está cobrindo a vossa ovelhinha branca! De pé! De pé! Mandai tocar a rebate! Despertai os burgueses do seu ronco! Rápido! rápido! enquanto o diabo, num esfregar de olhos, não vos faz um neto! Rápido! já! (Ato I, Cena I, grifos nossos); [...] Viemos aqui para vos prestar um serviço. Mas como nos tomastes logo por bandoleiros, o resultado é que vereis a vossa filha coberta por um cavalo da Berberia. Quereis que os vossos netos relinchem para vos pedir a bênção? Agrada-vos uma parentela de corcéis e ginetes? (Ato I, Cena I, grifo nosso).

Lévi-Strauss (1976), citando Arthur Gobineau (1816-1882), diz que este, para quem a história fez o pai das teorias racistas, não concebia a "desigualdade das raças humanas” de uma maneira quantitativa, mas qualitativa; assim, para Gobineau, "a tara de degenerescência [...] estava ligada mais ao fenômeno de mestiçagem” (LÉVI-STRAUSS, 1976, p. 53). De acordo com Everardo P. Guimarães Rocha (2003), o etnocentrismo é uma visão do mundo na qual "o nosso próprio grupo é tomado como centro de tudo e todos os outros são pensados e sentidos através dos nossos valores, nossos modelos, nossas definições do que é a existência." (ROCHA, 2003, p.7). E amplia a definição afirmando que no plano intelectual tal visão se dá como a dificuldade de se pensar a diferença, enquanto no plano afetivo como sentimentos de estranheza, medo, hostilidade, etc. Porém é ainda Lévi-Strauss (1976, p. 59) quem melhor aprofunda essa definição:

A atitude mais antiga e que repousa, sem dúvida, sobre fundamentos psicológicos sólidos, pois que tende a reaparecer em cada um de nós quando somos colocados numa situação inesperada, consiste em repudiar pura e simplesmente as formas culturais, morais, religiosas, sociais e estéticas mais afastadas daquelas com que nos identificamos. 'Costumes de selvagens', 'isso não é nosso', 'não deveríamos permitir isso', etc., um sem número de reações grosseiras que traduzem este mesmo calafrio, esta mesma repulsa, em presença de maneiras de viver, de crer ou de pensar que nos são estranhas. Deste modo a Antiguidade confundia tudo o que não participava da cultura grega (depois grecoromana) sob o nome de bárbaro; em seguida, a civilização ocidental utilizou o termo de selvagem no mesmo sentido. (LEVI-STRAUSS, 1976, p. 59)

De outro modo, citou-se que os dicionários mais respeitáveis trazem para a palavra mouro termos como "moreno, trigueiro”, “a dark-skinned person”, "não batizado". Dessa forma, quando se referem a Otelo, os personagens 
shakespearianos projetam-lhe as mais depreciativas associações, tais como compará-lo a animais, ou ao próprio diabo, em expressões as mais diversas disseminadas no corpo da peça como, por exemplo, "um ser feito para inspirar terror e não prazer", “um bruxo”, “débil mouro”. Lévi-Strauss (1976, p. 59) afirma existir por detrás de epítetos semelhantes a estes, dissimulado, um mesmo juízo:

É provável que a palavra bárbaro se refira etimologicamente à confusão e à desarticulação do canto das aves, opostas ao valor significante da linguagem humana; e selvagem, que significa 'da floresta', evoca também um gênero de vida animal, por oposição à cultura humana. (LEVISTRAUSS, 1976, p. 59)

Para o autor de Raça e História (1976), as atitudes da citação anterior se fundamentam numa recusa em se admitir a própria diversidade cultural, preferindo repetir da cultura tudo aquilo que esteja conforme à norma sob a qual se vive.

E é também Campos (2000, p. 4) quem observa que "os estereótipos criados para moldar a imagem do mouro são tão poderosos que o próprio Otelo começa a ecoá-los quando diz que Desdêmona tinha olhos para ver e o escolheu”. E tal escolha, nas palavras de Iago, seria uma "depravação de gosto”, o que Otelo já parece disposto a aceitar, senão vejam:

(IAGO): Sejamos francos: recusar propostas de casamento, de ótimos partidos, de patrícios da mesma cor e meio, ao contrário do que seria natural... Isso não cheira bem... Faz pensar em instintos viciosos... anormais inclinações... depravação de gosto... Mas, perdão! Não é dela que falo especialmente... ainda que seja para recear que ela caindo em si, comece a comparar-vos com os seus patrícios e depois... quem sabe? Talvez acabe por se arrepender... (Ato III, Cena III).

(OTELO): Talvez por eu ser negro e não ter o falar adocicado e as maneiras suaves dos galantes da corte... (Ato III, Cena III).

Assim, para a referida autora, Otelo não é apenas negro, ou só mouro, ele representa o exótico, o desconhecido, quer dizer, o imaginário do europeu. Essa é também a opinião de Gillies (1994), também citado pela mesma autora, que afirma ser o exotismo de Otelo para os europeus tão perigoso quanto sua cor. Ademais, o mesmo Gillies observa como em Shakespeare todos os mouros são vistos como 
exóticos: "o exótico não só abraça o negro, o moreno, o monstruoso, o selvagem, o bárbaro, o Novo e Velho Mundo, mas toca todos com admiração e trata as versões antigas e renascentistas da alteridade (canibais e antropofágicos) como intercambiáveis."3 (tradução nossa) (GILLIES, 1994, p. 33 apud CAMPOS, 2000, p. 3).

\section{Assim é, se assim lhe parece?}

De modo inconcluso, este estudo pretendeu, inicialmente, abrir apenas perspectivas na investigação dessa característica tão pouco explorada do epíteto mouro do personagem Otelo, principalmente naquilo que é mais substancial no texto shakespeariano, isto é, a construção retórica da alteridade do personagem. Ademais, é sabido que tal qualificativo aparece em outros textos shakespearianos, e aqui lembraria, principalmente, a tragédia Titus Andronicus e a comédia $A$ Midsummer Night's Dream. Em Titus Andronicus, por exemplo, aparece o personagem mouro Aarão, amante de Tamora, que “dá à luz uma criança negra.” E ainda sobre ele são lançados os epítetos mais significativos como "negro cimeriano”, "mouro bárbaro”, “amante negro como corvo”, "Aarão terá a alma tão negra quanto a face"; enquanto em A Midsummer Night's Dream, no Ato III, Cena 2, surge a expressão: “Away, you Etíope!”. É de se concluir, assim, que essa pesquisa apenas começou, não sendo por conseguinte conclusiva, e terá, certamente, de ser aprofundada com a agregação de dados outros provenientes dos próprios textos shakespearianos.

Entretanto, ao se fazer tal ressalva, nada impede que arrisque algumas considerações provisórias sobre a questão. Ao finalizar o último capítulo com uma declaração de Iago sobre Otelo ("E se não é como devia, então prouvesse aos Céus que o fosse"), sente-se que Otelo não consegue ter existência própria, ele é verdadeiramente "o outro", o Mouro, o bárbaro, o exótico, o oriental a serviço de

\footnotetext{
3 "the exotic not only embraces the black, the tawny, the monstrous, the savage, the barbarous, the New World and the Old, but touches all with wonder and treats the ancient and Renaissance versions of otherness (cannibals and antropophagi) as interchangeable". (GILLIES, 1994, p. 33 apud CAMPOS, 2000, p. 3).
} 
um Estado decadente e de seus súditos. Como afirma, preconceituosamente, o próprio Marx, sobre os orientais: “Não podem representar a si mesmos; devem ser representados." (MARX apud SAID, 1990, p. 11). Tolerado, apenas porque necessário. Amado, não pelo que é, mas pelo que representa, uma imagem grandiosamente construída de alguém diferente - ele é um Mouro, um oriental, um exótico -, porém distorcida. Nesse sentido, pode ser tanto o Mouro "infiel”, quanto o negro "mais branco que escuro", porque é tão somente a medida dos limites e frustrações daqueles que o criaram, e que representa uma visão de mundo elisabetana que infelizmente se projetou até nossa época.

Como bem lembra Danielle Forget (2001, p. 10), na obra coletiva Imagens do Outro: leituras divergentes da alteridade: “à questão: 'quem é o Outro?' que deveria merecer todo nosso cuidado, [...], poder-se-ia responder minimamente afirmando que: o Outro é um produto de nossas imagens mentais (onde se inclui o cultural) e de suas apropriações pelos discursos." Quer dizer, responder a esse questionamento tem sua relevância na construção/desconstrução do próprio texto literário, na medida em que reflete verossimilmente aspectos externos à obra - sua ambiência - e que, de algum modo, inflectem na sua configuração. Se não fosse por isso:

Tentar compreender a alteridade, isto é, a relação com os/as outros/as, é um tema candente no cenário internacional contemporâneo. A xenofobia e o racismo, as guerras étnicas, o preconceito e a discriminação baseadas na raça, na etnia, no gênero, na idade ou na classe social são todos fenômenos amplamente disseminados no mundo, e que implicam em altos graus de violência. Todos eles são manifestações de não reconhecimento dos/das outros/as como seres humanos cabais, com os mesmos direitos que os nossos. (JELIN, s.n.t.)

Não é sem razão que toda uma forma de olhar, de ver o Outro, de sua não aceitação, foi a responsável historicamente por todo um comportamento que sempre desaguou em conflitos sangrentos, dentre os quais as Cruzadas são do passado o exemplo mais pungente.

Sendo assim, quem seria verdadeiramente esse Otelo, esse "Mouro de Veneza", do qual Shakespeare fez questão em manter o epíteto herdado de Cinthio? 
Um árabe, por conseguinte um "infiel” para os padrões da época? Um "soldado negro mercenário", "tolerado" por um ocidente branco e cristão? - Otelo era batizado. Ou tão somente, como o próprio $\mathrm{Iago}^{4}$, uma construção tipicamente ocidental, que vem a se situar naquele contexto que Edward Said (1990, p. 8o) tão bem denunciou:

No poema de Dante, na obra de Pedro, o Venerável, e de outros orientalistas de Cluny, nos escritos dos polemistas cristãos contra o islã, desde Guibert de Nogent e Beda até Roger Bacon, Guilherme de Trípoli, Burchard de Monte Sião e Lutero, no Poema del Cid, na Chanson de Roland e no Otelo (aquele 'abusador do mundo') de Shakespeare, o Oriente e o islã sempre são representados como entidades externas com um papel a cumprir dentro da Europa. (SAID, 1990, p. 80)

\section{Referências}

ALCORÃO SAGRADO. Trad. Prof. Samir el - Hayek. 13. ed. São Paulo: MarsaM, 2004 .

AFRICANUS, Leo. The History and Description of Africa (160o). Disponível em:< http://www.universalteacher.org.uk/shakespeare/othello1.htm>. Acesso em: dez. 2006.

AZEVEDO, Antonio C. do Amaral. Dicionário de nomes, termos e conceitos históricos (com a colaboração de Rodrigo Lacerda). Rio de Janeiro: Nova Fronteira, 1990.

BANDEIRA, Manuel. Elisabete censurada II. In: . Andorinha, Andorinha. Rio de Janeiro: Nova Aguilar, 1990.

A linguagem shakespeariana de Onestaldo de Pennafort. In: Rio de Janeiro: Jornal do Brasil, 10 mar. 1956.

BLOOM, Harold. Shakespeare: a invenção do humano. Trad. José Roberto O’Shea. Rio de Janeiro: Objetiva, 2001.

CAMPOS, Sirlei Santos. O trágico como a experiência de alteridade em Otelo, de Shakespeare. Revista GT dramaturgia e teatro, n. o, 2000.

\footnotetext{
${ }^{4} \mathrm{Na}$ novela original o Mouro não tem nome, sendo chamado apenas pelo epíteto, como o lago da tragédia, que no conto é denominado somente de Alferes.
} 
CAVENDISH, Sueli. Conversa franca. Revista Continente Multicultural, Recife, ano II, n. 17, maio 2002.

CELI, Adolfo. Otelo: Shakespeare/Pennafort. In: PENNAFORT, Onestaldo de. Otelo. 3. ed. rev. Rio de Janeiro: Civilização Brasileira, 1968.

FORGET, Danielle; OLIVEIRA, Humberto Luís L. de. (orgs.) Imagens do outro: leituras divergentes da alteridade. Feira de Santana, BA: UEFS-ABECAN, 2001. GRANDE ENCICLOPÉDIA LAROUSSE CULTURAL. Rio de Janeiro: Nova Cultural, 1998.

JELIN, Elizabeth. Cidadania e alteridade: o reconhecimento da pluralidade. s.n.t. LELLO. Dicionário prático ilustrado. ed. atual. e aum. Porto: Lello \& Irmãos, 1960. LEVI-STRAUSS, Claude. Raça e história. In: Seleção de textos. Os Pensadores. 1. ed. São Paulo: Abril Cultural, 1976.

LONG, Bill. Othello's manner of speaking and Othello. Disponível em: $<$ www.drbilllong.com/index.html $>$. Acesso em: dez. 2006.

- The tragedy of Othello: the moor of Venice. Disponível em: <www.drbilllong.com/index.html>. Acesso em: dez. 2006.

MEDEIROS, F. C. de Almeida. Sinopse, dados históricos e notas de rodapé a cada obra. In: SHAKESPEARE, William. Obra completa. Volume I. Tragédias. Rio de Janeiro: Nova Aguilar, 1969.

MOISÉS, Massaud. Dicionário de termos literários. 11. ed. São Paulo: Cultrix, 2002.. ONESTALDO DE PENNAFORT (1902-1987). Disponível em: < Itaú Cultural panorama poesia e crônica >. Acesso em: dez. 2006.

Othello's Predecessors: moors in renaissance popular literature. Disponível em: $<$ Folger Shakespeare Library >. Acesso em: dez. 2006.

PENNAFORT, Onestaldo de. Alguns aspectos de Otelo. In: SHAKESPEARE, William. Otelo. Trad. de Onestaldo de Pennafort. 3. ed. rev. Rio de Janeiro: Civilização Brasileira, 1968.

REBOUL, Olivier. Introdução à retórica. São Paulo: Martins Fontes, 1998.

ROCHA, Everardo P. Guimarães. O que é etnocentrismo. 1. ed. 18. reimp. São Paulo: Brasiliense, 2003. 
SAÏD, Edward. Orientalismo: o oriente como invenção do ocidente. Trad. Tomás Rosa Bueno. São Paulo: Companhia das Letras, 1990.

SHAKESPEARE, William. Otelo. 3. ed. rev. Trad. de Onestaldo de Pennafort. Rio de Janeiro: Civilização Brasileira, 1968.

. Obra completa. Volume I. Tragédias. Sinopse, dados históricos e notas de rodapé a cada obra, de F. Carlos Almeida de Cunha Medeiros. Rio de Janeiro: Nova Aguilar, 1969.

THE AMERICAN HERITAGE DICTIONARY OF THE ENGLISH LANGUAGE. Fourth edition. : Houghton Mifflin Company, 1975.

The tragedy of Othello, moor of Venice by William Shakespeare. Disponível em: $<$ Project Gutenberg Association/Carnegie Mellon University>. Acesso em: dez. 2006.

The literature network. Disponível em: <http://www.universalteacher.org.uk/shakespeare/othello1.htm>. Acesso em: dez. 2006.

\footnotetext{
* Doutor em Estudos Literários. Professor da Faculdade de Letras - FALE da Universidade Federal de Alagoas.
} 